\title{
DEFINITIONS AND SCIENTIFIC CONTEXT OF THE SCIENCE OF COMMODITIES
}

\author{
Alexandru BURDA \\ Dimitrie Cantemir Christian University \\ E-mail: alex.burda@mail.com \\ Sebastian CHIRIMBU \\ Spiru Haret University/PhD Valahia University of Târgovişte \\ E-mail: sebastian_chirimbu@yahoo.com
}

\begin{abstract}
The Science of Commodities as an independent discipline studies the level of satisfaction of implicit and explicit needs through quality and assortment of goods. In time, this scientific area has held various names. The best known of these names is the "Commodities". The term "Commodities" is equivalent in Romanian with "study (science) goods". The phrase "knowledge goods" was borrowed from Italian, which was formed from the Latin expression mercis (= the commodity) and Greek expression $\lambda \circ \gamma_{0} \xi$, logos (= science, knowledge) deeper, state, Commodities that name comes from the Latin word MERX, which is mercis genitiv.
\end{abstract}

Key-words: quality, science, commodities, consumer, goods

JEL Classification: $\mathrm{A}_{14}$

\section{Introduction}

The Science of Commodities emerged and developed from practical requirements in all countries. As a result, in various languages, the phrase has been translated alone or in equivalent terms.

In Romania the first name of Commodity Knowledge appeared for the first time in a book published in 1879 entitled "Commodities trading Manual for knowledge of goods" author N. Mallian - Professor of Accounting and Commercial goods Public School in Craiova. Also in Romania in 1895, Arsenie Vlaicu published in Brasov the first manual of classic Commodities entitled „Commodity and technology professional trade schools and private study”. In this respect, Arsenie Vlaicu is considered a valuable precursor of modern Commodity science in Romania because in his view the Science of Commodities received a fuller definition. From its inception until the twentieth century, the notion of Commodity Science knew three types of definitions:

- Science of Commodities is the study of the properties, of the derivation and analysis, as well as the social importance of the goods. This definition belong to the first professor of higher education in Göttingen, Johann Beckmann (1739-1811); 
- Science of Commodities is the science of all types of goods. The author of this definition was Professor of Mannheim, Viktor Poschl (1884-1948);

- Science of Commodities is the science of examining the goods. Definition belongs to $\mathrm{H}$. Thomas and J. Holfert, but also in Germany. K. Ohara (Germany) expressed the same definition, adding that „Commodity is a science that examines the goods in terms of the merchant and the buyer."

To these three definitions, can be added a fourth one, given by Arsenie Vlaicu: Science of Commodities is the original study, of obtaining, essential properties of the physical and chemical indicators of life and goodness, and means to establish these qualities and discover the alterations and falsification goods. For the period, in a modern vision, the focus is on the study of the use value of goods.

Theoretical background

The need to know the importance of goods and their commercial importance is ancient, being connected to stage of exchange, which involved a fair assessment of the value of the goods exchanged. The first investigations and research were made by doctors on drugs and medicines. The literature considers the beginnings of the Science of Commodity in the work of Johann Beckmann "Commodities preparatory course or the knowledge of the best goods from abroad" (Göttingen 1793-1800). In this regard, it is noted that in Italy the first Treaty of weights, measures and trade of goods belonging to Francesco Balducci Pegolotti (XIV) was published in Florence in 1440.

In Germany, the first attempts to describe and systematize the goods dates from seventeenth century. In our country the interest for the study goods starts with the establishment of the commercial and industrial schools in Bucharest and Craiova (1880) and Galati (1864), and of the Academy of High Commercial and Industrial Studies in Bucharest (1913) and Cluj (1920). The main period of the Science of Commodities developments are set to be:

- The period of the precursors characterized by the creation of a new field of study, specialized in connection with development of economy and trade;

- The Science of Commodities founding period, which clarifies the relationship with related science and technology in particular;

- General Science of Commodities Period (circa 1810-1870), in which progress has been made on counterfeiting, methods of preservation and storing of goods;

- The period of technical Science of Commodities studies, along with the flourishing trade in the colonies;

- The period of modern trends starting from the third decade of the $\mathrm{XX}^{\text {th }}$ century, has two associated current of the Science of Commodities: Technological Science of Commodities (characterizes goods in technical terms and not in terms of their characteristics) and the teleological Science of Commodities (characterized by emphasizing the purpose for using the goods and treating the subject predominantly in merceological terms, with the appropriate limitation of the technological descriptions). 


\section{Defining the Science of Commodities}

In line with the foregoing, it can be stated that the Study of goods or the Science of Commodities rapidly evolved in the $2^{\text {nd }}$ half of the twentieth century from being a classic study, the one in which the emphasis is on in-depth study of the properties, quality characteristics, the defects and fault detection, the interaction between the product (system component) and environment, to the modern status of a study of goods as a two-component system (product and packaging) in connection with technical and socio-economic factors that are involved in the development, distribution and consumption of goods. Depending on the foregoing, one of the essential characteristics of modernization of production and trade with goods is reconsidering the goods as two-component system products goods-packaging. Currently a reconsideration of the Science of Commodities as a tricomponent system product - packaging - the environment is required. In this way packaging is integrated in the concept of total package.

The Science of Commodities as a discipline studying the physical and chemical properties of the goods in respect of quality and storage and has two sub-branches main profile:

- Industrial commodities (non-food) is that part of studying the quality and range of non-food products derived from inorganic materials with high degree of industrial processing.

- Food Commodities is part of studying the quality and range of food products derived from raw materials of organic origin, animal or vegetable, with low processing time and use limited food value and taste mainly determine their characteristics quality.

The Science of Commodities as a discipline, studies the properties of the goods. Properties and quality of goods gives utility in relation with market requirements to meet consumer needs. Due to the complex and dynamic quality goods Commodity science is studied in technical, economic and social terms.

These points of view are inseparable functions and are in close interdependence. In the modern concept of quality of life, the Science of Commodities is assigned the following functions:

- The propelling function with an impact in production, which relates to quality improvement, redesign and upgrade the products;

- The function of hierarchy of use values for their correlation with the quality and cost of products;

- The economic function manifested by the influence of the Science of Commodities on production, with the aim of adapting to consumer demands;

- The social function resulting from the role of the Science of Commodities in enhancing the utility of the manufactured products and therefore of the consumer requirements; 
- The educational function exercised by explaining the qualitative characteristics of products, aim to achieve a proper use of products by introducing new products in consumption and by creating new needs;

- The rationalizing of the consumption function, the masses aware of the consumer to buy the most suitable products according to their wishes and needs.

The connections of the Science of Commodities with other sciences

The Science of Commodities is part of the frontier sciences, with a deep economic and social outlook. The Science of Commodities is strongly interrelated with other disciplines as merchandise is investigated as a technical and socioeconomic structure that generates a system of relations with human needs, the environment or other complementary goods for purposes of satisfying some needs. These disciplines include: quality;

- Technology studying the influence the technological process on product

- Biology with Science of Commodities studying substances from various plants and their influence on consumer health;

- Justice science that is necessary to know the laws and regulations in force regarding the products sold;

- Marketing establishes consumer requirements cannot be known without a market survey and the production and sale of goods requires good logistics, appropriate publicity and location wise commercial network;

- Chemistry establishes the chemical composition of the goods both in laboratory tests and the consumer;

- Physics, particularly electrical and electronic goods, by checking the technical and functional characteristics.

The Science of commodities it is also science related with other scientific subjects: mathematics, economics, management and informatics. In this sense, one can conclude that the Science of Commodities is a discipline with a deep interdisciplinary, increasing the usefulness and quality of goods.

Types of analysis used in the research of goods

Scientific research of consumer goods uses methods such as structural analysis, comparative analysis, system analysis, functional analysis, brainstorming method, value analysis and morphological analysis. Each one helps individually or associated with each of the other methods resulting in better knowledge of the goods as such and of their quality, based on the needs that they have to satisfy. 
Figure no. 1. The connections of the Science of Commodities with other sciences

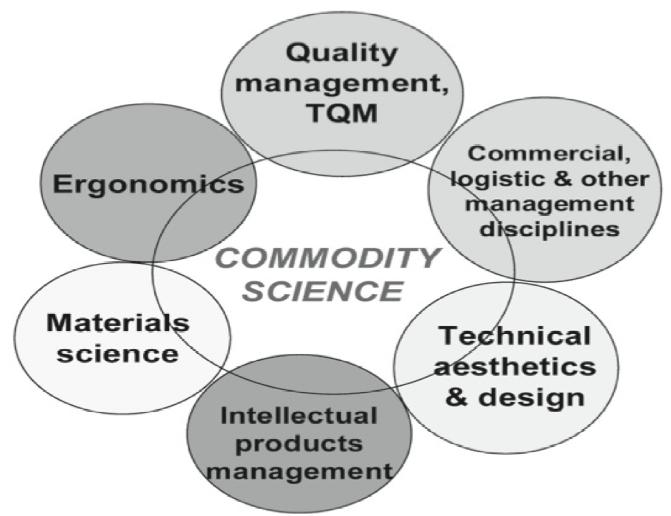

Source: the author

- Structural analysis is used for analysing the structure of the product;

- Comparative analysis compares the local products, imported products, but similar utilities;

- Systemic analysis refers to the ratio produced - need - cost - economic and social efficiency. The main properties of the goods must be reported on the cost of products and consumer needs. Product quality should result in obtaining the most optimal cost for both producer and consumer.

- Functional analysis applies to products with a high degree of technicality and determines the technical-functional characteristics;

- Brainstorming method aims to identify the group of the best ideas for new products / services. It has made a systematic screening of ideas, to identify the best solution, on which the decision to apply in practice;

- Value analysis (technical and economic) follows each product/service setting reasonable correlation between intake parts, sub-assemblies or functions (properties, characteristics) utility (use value of the whole) reported: cost and degree of satisfaction of need. The purpose of the analysis is to reduce unnecessary costs and increase product quality by optimizing functions.

- Morphological analysis devised by Zwicky involves achieving the next step: decomposition product according to its most important dimensions; for each dimension searching all possible solutions; to carry out the combination of the solutions identified in order to find new product ideas.

For example, a product may be broken down into four areas: A, B, C and D. Each size is specific to particular solutions:

The size, there are solutions $\mathrm{A} 1, \mathrm{~A} 2, \mathrm{~A} 3$, and so on; size $\mathrm{B}$, there are solutions B1, B2, B3, etc. By combining solutions of each dimension may result new ideas, such as A3B1C2D3.

Science of commodities presents some important features as multi and interdisciplinary character, dynamics and practical and formative character. 


\section{Conclusion}

The Science of Commodities covers a very broad issue, its core consisting of tradable - merchandise. Thus the Science of Commodity studies goods in the field of technical-economic in all its activities, in which feedback highlights the evolution in time and space of their quality. All these factors underline the complex, interdisciplinary, standing and consistent, dynamic and adaptable, but also the science practical formative and informative of the Science of Commodities.

So it can be stated that the Science of Commodities has a commercial importance underlined by the functions it performs: technical, economic, social, with systemic implications on the goods in the information flow (needs production - trade - consumer - environment).

\section{References}

- Bologa, N. (2001) Merceologie alimentară (Food Commodities Science), Bucureşti: Editura Oscar Print.

- Bologa, N., \& Burda, A. (2006), Merceologie alimentară (Food Commodities Science), Bucureşti: Editura Universitară.

- Burda, A. (2011), Bunuri alimentare (Food Commodities), Bucureşti: Editura Universitară.

- Burda, A. (2009) „Evoluţii şi tendinţe europene în obţinerea şi asigurarea calităţii bunurilor alimentare" ("European evolutions and trends in obtaining and asuring food quality”). „Demos”, Evoluţii în procesul integrării europene a României ("Demos”, Developments in the European integration of Romania), volumul II, Bucureşti: Editura Pro Universitaria.

- Burda, A. (2008), “Calitatea produselor alimentare - definire conceptuală şi legală în procesul de integrare a pieţei alimentare româneşti în cadrul pieţei comunitare" ("Food quality - conceptual and legal definition in the process of integration of the Romanian food market integration within the European food market”). România - Uniunea Europeană. De la aderare la integrare (Romania - European Union. From joining to the integration). volumul II, Bucureşti: Editura Pro Universitaria.

- Burda, A. (2006) „Gestiunea calităţii produselor alimentare prin mecanismul trasabilităţii" ("Food quality management through the traceability mechanism"). Analele Universităţii Creştine „Dimitrie Cantemir”, Seria Economie - Comerţ şi Turism (The Annals of "Dimitrie Cantemir" Christian University, Economy - Commerce and Turism Series), Bucureşti: Editura Pro Universitaria.

- Diaconescu, I. (2004), Merceologie alimentară (Food Commodities Science), Bucureşti: Editura Qlassroom.

- Dima, D., \& Diaconescu, I. (2005), Fundamentele ştiinţei mărfurilor: mărfuri alimentare (Fundamentals of the Science of Commodities: food commodities), Bucureşti: Editura ASE. 
- Olaru, M., Schileru, I., Băietoniu, P., Pamfilie, R., Părăian, E., \& Purcărea, A. (2005) Fundamentele ştiinţei mărfurilor (Fundamentals of the Science of Commodities), Bucureşti: Editura Economică.

- Pascu, E. (2012), Noţiuni privind calitatea produselor şi serviciilor - instrument în activităţi economice (Notions regarding the quality of products and services - instrument in economic activities). Bucureşti: Editura Universitară.

- Pascu, E., Părăian, E., \& Stanciu, I. (2012), Fundamentele ştiinţei mărfurilor. Manual de studiu individual (Fundamentals of the Science of Commodities. Individual learning manual). Bucureşti: Editura Universitară. 

Redactor: Mihaela N. ŞTEFAN

Tehnoredactor: Marcela OLARU

Coperta: Magdalena ILIE

Bun de tipar: 29.09.2015; Coli tipar: 4 Format: $16 / 70 \times 100$

Editura Fundaţiei România de Mâine Str. Fabricii nr. 46G, Bucureşti, Sector 6 Tel./Fax: 021/444.20.91; www.spiruharet.ro e-mail: editurafrm@ spiruharet.ro 
